\title{
The Discrediting of Competing Trademarks - Between Multiple Qualification Option and Qualification Impediment
}

\section{Iulian MORARU*}

\begin{abstract}
Discrediting competing trademarks consists in the spread of certain information regarding the trademarks owned by the competitor of the undertaking realising the disparaging actions. Relating the idea to the legislative provisions in force of the Republic of Moldova, it can be inferred that there are two options for qualifying such a conduct-according to the rules of unfair competition and in accordance with the rules of dishonest advertising. In such circumstances, the obvious question raised is whether the qualification will be done in accordance with one or another relevant legal norm. This aspect requires a broad clarification in the sense of offering viable alternative solutions and corresponding to the various practical factual situations. In this context, it is necessary to establish defined criteria in material and procedural terms in order to achieve a clear delimitation between different qualifying vectors. Circumstantially, there is a need to resort to the approach of domestic practice in this matter, as well as to the treatment of legislative, theoretical and practical trends in other states and legal systems.
\end{abstract}

Keywords: discrediting, trademark, unfair competition, dishonest advertising, qualification.

JEL Code: K23.

\section{Introduction}

The main reason for the present research lies in the need to outline some theoretical and practical aspects regarding the qualification of trademarks

*Iulian MORARU is Ph.D. in law candidate at Moldova State University, Chișinău, Republic of Moldova. E-mail: iulian.moraru94@gmail.com 
discrediting by unfair competitors, as well as the primary problems which may arise out in the qualification process.

The importance of such research is explained by the actual tendencies in the economic activity of undertakings to promote themselves by means of discrediting their competitors' person, economic activity or products.

The practical relevance of the researched subject consists of creating a consolidated vision regarding the doctrinal, legal and institutional approaches tangent to the researched field.

In the context of this research, it is proposed to reach the following proposed objectives:

- To determine the origin of the unfair competition act of discrediting a competitor;

- To understand the ways in which the unfair competition act of discrediting a competitor is regulated in the actual legislative specter of Republic of Moldova;

- To expose the criteria by which the discrediting competitor may be qualified in a certain way;

- To infer international legislative trends in the researched domain;

- To identify the most relevant national and international practice in the researched area.

In order to reach the above mentioned objects, we propose the consecutive approach of the following aspects: (i) The evocation of the historical origin of the unfair competition act of discrediting a competitor; (ii) Drawing the problem of qualification of discrediting a competing trademark; (iii) Revealing the relevant theoretical and practical criteria by which a certain act may be qualified; (iv) Examining the relevant international legislative trends in the researched area; (v) Studying the national and international practice in the domain of discrediting a competitor's trademark.

\section{Literature review}

The relevant literature in the matter is not a rich one in the quantitative aspect, or a limited number of authors have written by the moment on the 
subject in question. Among the mentioned sources, it is worth specifying the following ones:

- Gorincioi, C. (2019). Cercetarea instrumentelor juridice de contracarare a actelor de concurență neloială. Teză de doctor în drept. [Research of legal instruments of counteracting the unfair competition acts. Doctoral thesis in law] This source is an integrated synthesis of the specifics of the system of unfair competition actions, as well as of the available legal mechanisms to counteract these actions. The theoretical significance of the thesis lies in the fact that the author approaches the topic concerning the main differences between unfair competition and inadequate advertising.

- Andraško, J. Sopúchová, S.R. (2016). Limitations of comparative advertising permissibility: denigration/disparagement. This source is a practical point of view concerning different approaches towards limitations of comparative advertising. It was primarily used for the purpose of studying the relevant European case law dealing with the researched topic.

- Castraveț, D. (2019). Răspunderea civilă delictuală pentru actele de concurență neloială. Teză de doctor în drept. [Tortious civil liability for acts of unfair competition. Doctoral thesis in law]. This paper is a bibliographical reference for consultation in the sense of diversifying the views expressed by various researchers in the field of approach.

- WIPO Model Provision on Protection Against Unfair Competition (1996). The mentioned source has been used in the scope of determining the content of discrediting a competitor unfair competition act.

- WIPO Handbook on Intellectual Property (2004). This source has been used for the purpose of identifying the regulation trends in the field of the researched topic at the international level.

\section{Methodology}

The methodological arsenal used in the context of the elaboration of this paper consists in particular of:

- The historical method. The use of that method contributes, in particular, to the identification of the historical origin from the normative point of view of the concept of discrediting in the system of unfair competition actions, as well 
as the evolutionary course of the given concept, until its introduction in competition and related legislation at national level;

- Logical-formal method. The benefit of using this method lies in the possibility of a proper analysis of theoretical ideas, as well as previous practical findings through deduction and induction operations in order to identify the compliance of those findings with the related regulatory trends;

- Legal-comparative method. In view of the application of this research method, the necessary conditions are created in order to contrast the theoreticalpractical and legislative aspects, as a result of which relevant conclusions can be drawn in order to improve the existing conceptual framework and unify current practice.

Apart from that, during the research there will be also used the content analysis method and the analysis of social, official, public, numerical and nonnumerical documents.

All the methods listed and analyzed above will be used alternatively and as a whole.

\section{The origin and significance of the concept of 'discredit'}

The term "discredit" comes from the French "discrediter" and means, according to the Explanatory Dictionary of the Romanian Language, "to make lose or lose one's credit, consideration, trust of others; to (commit)".

\section{Use of the term in Law on competition no. 183 of 11.07.2012}

It is worth mentioning that the term "discredit" is used in the text of art. 15 of the Law on competition no. 183 of 11.07.2012 in two alternative normative ways:

a) Indirect discrediting

b) Direct discrediting

The normative meaning of the term "discrediting" is similar to that of the Explanatory Dictionary of the Romanian Language. 


\section{The need to approach the proposed topic}

In practical terms, from a normative point of view, the discrediting of the competitor is dispersed in two distinct normative acts: Law on competition no. 183 of 11.07 .2012 (art. 15) and the Law on advertising no. 1227 of 27.06.1997 (art. 9 para. (1) letter b)).

Thus, according to the provisions of art. 15 of the Law on competition no. 183 of 11.07 .2012 , "It is forbidden to discredit competitors, namely to defame or endanger their reputation or credibility by:

a) the spread by an undertaking of false information about its activity, about its products, meant to create a favorable situation in relation to some competitors;

b) the spread by an undertaking of false statements about the activity of a competitor or about its products, statements that harm the activity of the competitor".

Contextually, in accordance with the provisions of art. 9 para. (1) lit. b) of the Law on Advertising no. 1227 of 27.06.1997, "It is considered dishonest advertising that: b) contains incorrect comparisons of goods advertised with similar goods of another economic agent, as well as statements or images that harm the honor, dignity or professional reputation of the competitor."

From the wording of the provision of art. 9 para. (1) lit. b) of the Law on Advertising, there can be inferred two sub-modalities of manifestation of dishonest advertising:

a) Comparative advertising

b) Denigrating advertising

At the same time, certain contextual interferences may present nonauthentic advertising manifested by the production, supply or dissemination of advertising that does not correspond to the reality regarding the trademark of the producer, or according to the provisions of art. 10 para. (1) lit. a) of the Law on Advertising no. 1227 of 27.06.1997, "It is considered inauthentic advertising containing data that do not correspond to reality in terms of: a) some characteristics of the goods necessary for the consumer, indicated on the label: quality, composition, date of manufacture, destination, properties of consumption, conditions of use and care recommendations, compliance with 
the standard, the manufacturer's trademark, the origin and place of production of the goods...". However, we find that in that case there is no evidence of the presence of the discrediting element.

Apart from that, in the Criminal Code of Republic of Moldova, there is established criminal liability for comparative advertising. Thus, according to provisions of art. $246^{1}$ letter e) from the mentioned normative act, „Any act of unfair competition, including:...e) comparison for advertising purposes of goods produced or marketed by an economic operator with the goods of other economic agents shall be punished with a fine from 3000 to 4000 conventional units or with imprisonment of up to 1 year, with a fine, applied to the legal person, from 3500 to 5000 conventional units with deprivation of the right to exercise a certain activity for a period of every 1 to 5 years". But, due to the existence of other forms of liability for unfair competition act, this legal norm has proven not to be efficient, as there is no case law on the cited provision.

Apparently, those forms of manifestation of dishonest advertising involve certain points of interference with the unfair competition action of discrediting the competitor. Thus, disparaging advertising can be compared to the direct form of manifestation of unfair competition action of discrediting the competitor, and comparative advertising, in some respects, involves tangency with the indirect way of realizing the unfair competition action of discrediting the competitor. Such circumstances may involve certain qualifying difficulties.

In the existing doctrine, there have been revealed several criteria for distinguishing between competitive discrediting and dishonest advertising in the forms of manifestation specified above. Thus, mainly, the following were noted:

a) Competitive discrediting involves competing companies as victims while dishonest advertising involves the victimization of consumers;

b) In case of discrediting, the spread of information may have specific addressees or a small circle of people, but dishonest advertising must be accessible to the general public;

c) The subject of discrediting is only the undertaking, but the subject of dishonest advertising activity can be any person.

At the same time, some procedural differences have been noticed. Thus, if the notification comes from a consumer, the rules of the legislation on 
advertising may be applied and, if necessary, of the Law on Consumer Protection will be applicable. On the other hand, if the complaint is filled by a competing undertaking, the facts are to be examined in the light of Law on competition no. 183 of 11.07.2012. (Gorincioi, 2019)

We consider the respective conclusions to be well-founded and, at the same time, we will put forward new hypotheses in that sense.

Thus, in the sense of a deeper examination of the aspects presented above, we consider the following similarities between the two extremes of the normative dispersion in question:

a) Both concern the reputation of the competing undertaking;

b) Both involve defamatory elements;

At the same time, there are a number of relevant differences in this regard that allow a clear distinction to be made between the two extremes:

a) Competitive discrediting imperatively implies the existence of false information, while disparaging advertising may even contain truthful statements.

b) Competitive discrediting may involve the spread of false information by transmitting it to a single person, while advertising is usually accessible to an indeterminate number of consumers.

c) Competitive discrediting is a formal action that sufficiently involves the spread of false information, regardless of the existence of an effect or injury, while disparaging advertising involves the actual damage to the honor, dignity or professional reputation of the competitor, as a result of accessible advertising to an indeterminate circle of consumers.

d) Competitive discrediting involves two alternative ways of manifestation (direct and indirect), while denigrating advertising can only affect the competitor directly; at the same time, comparative advertising may involve interferences with the indirect form of discrediting of the competitor.

Therefore, disparaging advertising and competitive discrediting have sufficient distinguishing points in the sense of achieving a delimited qualification.

\section{Conceptual problematic aspects regarding the discrediting of competing trademarks}


In the legislation of the Republic of Moldova, comparative advertising is a way of manifesting dishonest advertising, provided in the text of art. 9 para. (1) lit. b), prop. 1., which provides for 'incorrect comparisons', and the lack of a discrediting element is one of the criteria for determining the 'incorrect' rating of comparisons made in advertising.

Taking into account all the above considerations, we distinguish 4 options to qualify the action of discrediting competing trademarks:

a) Indirect discrediting, by spreading false information by the denigrating company about its own trademarks, thus being put in a favorable light in relation to the denigrated competitor;

b) Direct discrediting, by spreading false statements about the competitor's trademark, the action being meant to damage the latter's reputation;

c) Denigrating advertising, which involves an advertising activity that harms the honor, dignity or professional reputation of the competing undertaking by attacking the competitor's trademark

d) Comparative advertising, which puts the competitor's trademark in a negative light by making comparative assumptions between the trademark of the manufacturer, supplier or broadcaster of comparative advertising and its competitor (similar goods of another economic operator).

The first two qualifying alternatives represent normative modalities of the unfair competition action of discrediting the competitor, enshrined in the text of art. 15 of the Law on competition no. 183 of 11.07.2012, and the last two alternatives represent normative ways of manifesting of dishonest advertising, enshrined in the text of art. 9 para. (1) lit. b) of the Law on Advertising no. 1227 of 27.06.1997.

As an example, we will present the following hypothetical illustrations of the violations addressed in this paper:

a) Indirect discrediting. Undertaking X manufactures and sells household appliances and states that its Y-marked products have a number of advantages over other competing brands on the market due to its main characteristics. Thus, undertaking $\mathrm{X}$ disseminates false information about its own brand $\mathrm{Y}$ and places itself in a favorable light in relation to competing undertakings on that market. 
b) Direct discrediting. Undertaking $\mathrm{X}$ operates on the market for $\mathrm{Y}$ marked hotel services and spreads false information about the quality of services provided by undertaking $\mathrm{Z}$ with trademark $\mathrm{A}$, which is a directly competitive activity with Y trademark.

c) Denigrating advertising. Undertaking $\mathrm{X}$ places advertising material on a radio station that urges you not to purchase a particular $\mathrm{Y}$-marked product because of its poor quality.

d) Comparative advertising. Undertaking $\mathrm{X}$ places advertising by which it compares its own services provided under the $\mathrm{Y}$ trademark with the services of competitor A provided under the B trademark, thus putting in an unfavorable light the services provided by the competing company.

In practice, it is possible for the same action to bring together the constituent elements of several infringements set out above or to commit two separate acts. This circumstance is particularly relevant given that the same authority has jurisdiction to examine infringements of unfair competition and advertising law. Thus, according to the provisions of art. 39 lit. e) of the Law on competition no. 183 of 11.07.2012, "The Competition Council has the following main attributions: e) investigates anti-competitive practices, unfair competition and other violations of the legislation in the field of competition, state aid and advertising, within the limits of its competence ...".

\section{Conflict of qualification and cumulation of illicit acts}

\subsection{Conflict of qualification}

In the case of the simultaneous existence of signs of two distinct unlawful acts (signs of discrediting the competing trademark, on the one hand, and signs of disparaging or comparative advertising, on the other hand, the following aspects will be taken into account:

a) The dimensions of the illicit act, or the relation to the degree of spread of the respective information (a larger audience will be taken into account for the comparative advertising);

b) Competitive discrediting will always involve the spread of false information/statements, while in the case of advertising the lack of veracity is not a mandatory sign; 
c) Competitive discrediting is oriented towards a certain competitor, while the advertising implies the advertiser's intent to put in a favorable lights its product.

d) Competitive discrediting will be committed intentionally each time, while dishonest advertising could involve other forms of guilt.

e) The object of competitive discrediting will always be a competitor, while in the case of advertising, although made to the detriment of a competitor, the object may be different.

Procedural considerations may also be listed in order to resolve potential conflicts of qualification:

The author of the notification. If the complainant is directly the competitor whose legitimate interest has been affected by the actions of company X, then the administrative procedure before the Competition Council can be initiated based on the provisions of the competition legislation; on the contrary, in the case of advertising, the subject of the notification may be any person.

Form requirements. In the case of competitive discrediting, the complaint must correspond to the formalities of the form approved by the Decision of the Plenum of the Competition Council, in accordance with the provisions of art. 14 para. (2) and (3), art. 49 para. (2) - (4) and art. 51 para. (2) and (3) of the Law on competition no. 183 of 11.07.2012. Thus, according to the provisions of the norms from art. 14 para. (2) of the Law on competition, "Unfair competition actions prohibited by the provisions of art. 15-19 shall be examined by the Competition Council, upon the complaint regarding the alleged unfair competition actions filed by the undertaking whose legitimate interests have been harmed, under the conditions stipulated in art. 49 para. (2) - (4)". At the same time, in accordance with the provisions of para (3) of the nominated article, "The complaint regarding the alleged unfair competition actions shall be submitted according to the form adopted by decision of the Competition Council, under the conditions provided in art. 51 para. (2) and (3)".

The limitation period. Based on the provisions of art. 14 para. (5) of the Law on competition no. 183 of 11.07.2012, "The undertaking whose legitimate interests have been harmed may submit the complaint regarding the alleged unfair competition actions to the Competition Council within 6 months from 
the date on which it knew or should have known about the realization of the alleged unfair competition from another undertaking”.

\subsection{Cumulation of illicit acts}

In practice, it is possible to meet the qualifying elements of several types of infringements by committing possible deviations from the law. For instance, company $\mathrm{X}$, through a social network, spreads false information about the competitor's trademark Y (quality of products manufactured under the given trademark) - ideal cumulation or company $\mathrm{X}$ spreads false information about the brand of competing company $\mathrm{Y}$ through social networks and, at the same time, broadcasts through the audiovisual media denigrating advertising about the same products of the same competitor - real cumulation of illicit acts.

In such situations, the following question appears: can the contraventional liability coexist with the administrative one regarding the same act (in the case of the ideal cumulation of illicit acts) and regarding different but related acts (real cumulation of illicit acts).

Although there are several opinions regarding the coexistence of different forms of liability, we consider that in this case, administrative liability may coexist with contraventional liability, given the following relevant circumstances:

a) The authority to apply the sanction. In this case, the contraventional liability for dishonest advertising is applied by the court, and the administrative liability for competitive discrediting is applied by the national competition authority (Competition Council);

b) The act by which the sanctions are applied. The contravention liability is applied by means of a court decision, and the administrative liability by means of a decision of the Plenum of the Competition Council (unfavorable administrative act).

c) The normative act that governs the respective relations. The contraventional liability is applied based on the provisions of the Contravention Code of the Republic of Moldova, and the administrative liability is applied based on the provisions of the Law on competition no. 183 of 11.07.2012. 


\section{International trends}

In an international context, discrediting competing trademarks is assimilated to comparative advertising in many cases. In this respect, the WIPO model provisions on protection against unfair competition are relevant. Thus, according to the provisions of art. 5 para. (2) of the nominated act, 'Discrediting may arise out of advertising or promotion and may, in particular, occur with respect to (i) the manufacturing process of a product; (ii) the suitability of a product or service for a particular purpose; (iii) the quality or quantity or other characteristics of products or services; (iv) the conditions on which the products or services are offered or provided; (v) the price of products or services or the manner in which it is calculated. So, as it can be inferred from the cited provisions, the authors consider a direct link between discrediting and advertising, so that discrediting may arise out of advertising or promotion. However, it is not limited only to advertising.

In countries where emphasis is traditionally placed on the protection of honest entrepreneurs and their reputation, comparative advertising is either prohibited or at least severely restricted. Sometimes, the mere fact that a competitor's name is mentioned against his will is taken into account and, accordingly, the action is considered to be discrediting and therefore is considered to be unfair competition.

According to the rule that "the honest businessman has a right not to be spoken of, even if the truth is spoken", the legislation of some countries has expressly forbidden all comparisons that unnecessarily identify a competitor. The same argument has led courts in other states to consider comparative advertising automatically against fair commercial practices (and therefore against the general provisions on unfair competition). Although it has sometimes been pointed out that true comparisons may be in the interests of consumers, doctrine and case law have in practice allowed comparisons only in very special circumstances, for example, if they were expressly requested by a customer, if they were made to counter a illegal attack on the advertiser or if the comparison is necessary to explain certain systems or new technical developments in general. 
In recent years, however, this attitude towards comparative advertising has changed substantially. Thus, it is increasingly recognized that true comparative materials of relevant facts not only reduce the costs of searching for consumer information, but also have positive effects on the economy by improving market transparency. Courts in states that traditionally consider comparative advertising to be disparaging have gradually relaxed the strict prohibition on all statements identifying a competitor. For example, price comparisons based on true, relevant and comprehensive materials may be allowed. Overall, there seems to be a clear trend towards admitting truthful comparative advertising.

On the other hand, it cannot be denied that comparative advertising can more easily be misleading or disparaging than most other forms of advertising, for example if the comparison is based on irrelevant (or not really comparable) aspects, or if the overall impression is misleading. These potential dangers require special safeguards against abuse. Countries that allow comparisons place special emphasis on the fact that even true statements must not be unnecessarily disparaging or that irrelevant facts must not be compared.

In the same context, comparative advertising is often impossible without referring to a particular trademark that refers to a particular product, service or business. In such cases, in addition to advertising and unfair competition law, trademark protection law must be taken into account.

In states where trademarks are protected only as indications of the source of a product or service, the use of a trademark in comparative advertising may not fall within the scope of trademark protection law. However, there are states where the use of another person's trademark is made in comparative advertising, applicable to trademark protection law. (WIPO Handbook on Intellectual Property, 2004).

\section{Actuality}

\subsection{European Union}

At EU level, Directive 2006/114 / EC of the European Parliament and of the Council of 12 December 2006 on misleading and comparative advertising 
is in force. In the text of art. 4 lit. d), the following is stated: "Comparative advertising shall, as far as the comparison is concerned, be permitted when the following conditions are met::...d) it does not discredit or denigrate the trademarks, trade names, other distinguishing marks, goods, services, activities or circumstances of a competitor".

Therefore, at European level, the lack of the element of discrediting or denigrating competing brands is a criterion for the permissiveness of comparative advertising.

Thus, comparative advertising is allowed, as it can be very useful to consumers, provided that it is (i) true; (ii) non-misleading and (iii) meets the conditions of art. 4 of that Directive. One of the conditions given is that comparative advertising must not "discredit or denigrate the trademarks, trade names, other distinguishing marks, goods, services, activities or circumstances of a competitor".

Discrediting is a form of denigration and, since both are covered, no further distinctions are needed. However, not all comparative advertisements which discredit a competitor's trademarks must constitute discrediting within the meaning of that Directive, as any critical comparative advertising implies a certain discrediting of the competitor or its products. In the case of an absolute prohibition, the expected liberalization of comparative advertising would not have been achieved. Therefore, only in cases where advertising unduly discredits or denigrates a competitor's trademarks, trade names, products or activities, it should be considered illegal. In particular, where comparative advertising emphasizes the benefits of its own goods or services and reasonably highlights the disadvantages of the product of other competitors, there should not be any concerns regarding the lawfulness of the advertising material. On the other hand, comparative advertising that focuses only on the negative aspects of the competitor or its products is not acceptable. In the same context, discrediting can also result from an inappropriate and aggressive tone, unusual representation or assessment, or even non-specific, global rejection.

\subsection{United States of America}

In the US, the legislation on comparative advertising is relatively similar to that in the EU, but still more permissive than the latter, so that any kind of 
comparative advertising is allowed, except that which presents untrue information.

\section{Relevant practice}

\subsection{National practice}

A relevant case in this respect is the one solved by Decision no. $\mathrm{CN}$ 16/19-07 of 25.02.2020 (,Simplex-Co” S.R.L. against „Viloterm” S.R.L.). Thus, the Competition Council noted the following: “... signs of the discrediting action of the competitor were identified by the fact that it was spread by "Viloterm" S.R.L. of false claims about the products marketed by its competitor, namely that BAXI brand boilers are of poor quality and are produced in Turkey but not in Italy. Thus, it is noted that the company "Viloterm" S.R.L. did not have information regarding the inadequate quality of the BAXI boilers (in the context in which the defendant does not ensure their repair during the warranty and post-warranty period), but spread false information in this regard. This fact is certain and is confirmed by all the information resources accumulated in the process of conducting the investigation. The information presented by the representative of "Viloterm" S.R.L. consumers, during the telephone discussions, regarding the quality of the products, determined the buyers to give up the purchased product, returning it to the seller - „Simplex-Co" S.R.L. The respective statements of "Viloterm" S.R.L., having no evidentiary support, constitute in themselves actions that discredit and harm the activity of "Simplex-Co" S.R.L." Finally, the following were mentioned: „Based on the above, it is concluded that the company "Viloterm" S.R.L. took actions to discredit the competitor by spreading false statements about its products, statements that harm the activity of "SimplexCo" S.R.L. Thus, the violation of the provisions of art. 15 lit. b) of the Law on competition no. 183 of 11.07.2012". Respectively, the act of spreading false information about the competitor's products was qualified as direct discrediting".

Another relevant case is the one solved through the Decision of the Plenum of the Competition Council no. CN-50/19-30 of 09.07.2020 ("InvivoTech" S.R.L. against "Dermocosmetica" S.R.L.). Competition Council noted 
the following: "Thus, following the generation of all the accumulated materials, as a whole, the following are concluded: (i) the undertaking "Dermocosmetica" S.R.L. took both indirect and direct discrediting of the competitor by 1 . disseminating false information about its products and 2. about the competitor's products, which is detrimental to the latter's activity, given that the a) silences the expiry of European product certificates and b) discredits the competitor through the posts made within the social networks by the defendant's administrator; (ii) such actions jeopardize the reputation of the applicant undertaking and its products, and (iii) as a result, the risk of migration of the applicant undertaking's customers to the claimed undertaking is generated, which is likely to result in substantial losses in terms of regarding its main economic indicators addressed in the report ". Finally, the following were specified: "Based on the above, it is concluded that the company" Dermocosmetica" S.R.L. has undertaken actions to discredit the company "Invivo-Tech" S.R.L., by spreading false information about its own products, as well as about the economic activity of the competing company "InvivoTech" S.R.L. In this context, it was found the violation of the provisions of art. 15 of the Law on competition".

\subsection{International practice "British Airways against Ryanair Ltd (2001)"}

One of the most resonant cases dealing with comparative advertising, especially in terms of denigration, is British Airways v. Ryanair Ltd (2001). Ryanair organized a comparative advertising campaign in various UK publications in 1999. The first advertising material is known as 'Bastard' advertising (entitled 'EXPENSIVE BA... .DS!') And later 'Expensive' advertising. (title "EXPENSIVE BA"). That publicity appeared in February and March in several national periodicals. The "expensive" ad appeared only once in November, in the "Evening Standard". British Airways ('BA') is a registered trademark consisting of the letters BA registered for, inter alia, air travel services. The Advertising Standards Authority has been considering a complaint from the general public against the 'Bastard' advertisement. The Authority considered that such advertising material could cause significant damage to British Airways, but Ryanair Ltd undertook to cease the subsequent dissemination of that advertising. The second advertising material was the 
subject of an action for infringement of trademark rights and harmful falsity, but that action was ultimately rejected. (Andraško and Sopúchová, 2016)

\section{Conclusions}

All the issues addressed in the context of the elaboration of the scientific material in question allow the following general conclusions to be drawn:

- Discrediting competing trademarks implies the existence of multiple qualifying options;

- The respective qualification options are dispersed in distinct normative acts;

- The regulatory dispersion in question is likely to cause qualification impediments to the

Competition Council as the authority investigating the categories of cases;

- There are jurisdictions in which the discrediting of trademarks is an infringement, including based on the provisions of trademark protection legislation;

- Defining the criteria for delimiting different qualification options is a crucial aspect in order to achieve a correct qualification of the conduct of undertakings in their economic activity.

From our point of view, Competition Council has to examine all the relevant circumstances on a case by case basis for the purpose of identifying the correct solution for each practical situation. In this regard, there should be taken into consideration the above mentioned and discussed criteria.

\section{References:}

Andraško, J. Sopúchová, S.R. (2016). Limitations of comparative advertising permissibility: denigration/disparagement in: International and Comparative Law Review, pp. 117-125, retrieved from: https://www.researchgate.net/publication/322710522_Limitations_of_C omparative_Advertising_Permissibility_DenigrationDisparagement

Castraveț, D. (2019). Răspunderea civilă delictuală pentru actele de concurență neloială. Teză de doctor în drept. [Tortious civil liability for acts of unfair 
competition. Doctoral thesis in law], 197 p. Retrieved from: http://www.cnaa.md/files/theses/2019/55280/diana_castravet__thesis .pdf

Criminal Code of Republic of Moldova no. 985 of 18.04.2002. Retrieved from:https://www.legis.md/cautare/getResults?doc_id=125325\&lang=r o

Gorincioi, C. (2019). Cercetarea instrumentelor juridice de contracarare a actelor de concurență neloială. Teză de doctor în drept. [Research of legal instruments of counteracting the unfair competition acts. Doctoral thesis in law], 208 p., retrieved from: http://www.cnaa.md/files/theses/2019/54682/cornelia_gorincioi_thesis. pdf

Decision of the Competition Council Plenum no. CN-16/19-07 of 25.02.2020. Retrieved from https://competition.md/public/files /Decizia-CN-16-1907-neconf6b1d8.pdf

Decision of the Competition Council Plenum no. CN-50/19-30 of 09.07.2020. Retrieved from https://competition.md/public/files/Decizie2dfe5.pdf

Law on competition no. 183 of 11.07.2012. Retrieved from https://www.legis.md/cautare/getResults?doc_id=121240\&lang=ro

Law on advertising no. 1227 of 27.06.1997. Retrieved from https://www.legis.md/cautare/getResults?doc_id=109228\&lang=ro

Law on consumer protection no. 105 of 13.03.2003. Retrieved from https://www.legis.md/cautare/getResults?doc_id=110237\&lang=ro

Law on trademarks protection no. 38 of 29.02.2008. Retrieved from https://www.legis.md/cautare/getResults?doc_id=93464\&lang=ro

WIPO (1996). Model Provision on Protection Against Unfair Competition.Retrieved from https://www.wipo.int/edocs/pubdocs/en/intproperty/832/wipo_pub_832. pdf

WIPO (2004). Handbook on Intellectual Property. Retrieved from https://www.wipo.int/edocs/pubdocs/en/wipo_pub_489.pdf 